\title{
Static stress changes due to the 1998 and 2004 Krn Mountain (Slovenia) earthquakes and implications for future seismicity
}

\author{
A. Ganas ${ }^{1}$, A. Gosar ${ }^{2}$, and G. Drakatos ${ }^{1}$ \\ ${ }^{1}$ Geodynamics Institute, National Observatory of Athens, Lofos Nymfon, 11810 Athens, Greece \\ ${ }^{2}$ Environmental Agency of the Republic of Slovenia, Seismology and Geology Office Dunajska 47, 1000 Ljubljana, Slovenia
}

Received: 1 August 2007 - Revised: 2 January 2008 - Accepted: 2 January 2008 - Published: 8 February 2008

\begin{abstract}
In this paper we examine the Coulomb (static) stress pattern following the two moderate magnitude earthquakes in NW Slovenia during 1998 and 2004. These earthquakes ruptured patches of the NW-SE striking Ravne fault that crosses the Krn Mountain. The objective is to investigate the seismicity patterns for this area of Slovenia given that future earthquakes may be triggered as a result of stress changes along neighbouring faults. Our findings include: a) stress levels have increased along the active Ravne fault for all models discussed b) stress levels have decreased along the active, NW-SE striking Idrija fault and c) stress levels throughout the crust have increased along the E-W direction but have decreased in the N-S direction (stress shadow effect). We also mapped a better correlation of the off-fault aftershock locations with stress maps incorporating the regional stress field.
\end{abstract}

\section{Introduction}

In the last ten years, western Slovenia was struck by two strong earthquakes. The first event occurred on 12 April 1998 at 10:55 UTC with a moment magnitude of 5.6. The area that was affected was the Upper Soča valley and the Bovec basin (Fig. 1; Bajc et al., 2001; Zupančič et al., 2001). The total seismic moment was $4.5 \times 10^{17} \mathrm{Nm}\left(10^{24}\right.$ dyn-cm $)$ implying an average, co-seismic slip of $0.18 \mathrm{~m}$ (Bajc et al., 2001). There was no surface rupture. A second earthquake $\left(M_{w}=5.2\right)$ occurred on 12 July 2004 at 13:04 UTC to the northwest of the epicentre of the 1998 event (Fig. 1). Both events show right-lateral, strike-slip kinematics (Fig. 1; Bajc et al., 2001; Kastelic et al., 2006). In this paper we investigate a) the static stress change following the 1998 event

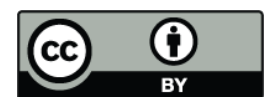

Correspondence to: A. Ganas

(aganas@gein.noa.gr) and b) the combined stress change following the 2004 event by applying stress transfer theory (Reasenberg and Simpson, 1992; Harris et al., 1995). Coulomb stress changes have explained the occurrence of large, future earthquakes along many fault zones (e.g. Stein et al., 1997; Nostro et al., 2005; Parsons et al., 2006). Our calculations show the effects of the combined Coulomb stress change in this region of Slovenia, including the location of stress shadows.

\section{Active tectonics and seismicity}

The active tectonics of western Slovenia is influenced by the continued northward indentation of the Adria microplate (approximately $2 \mathrm{~mm} /$ year; Battaglia et al., 2004; D'Agostino et al., 2005) which results in south-directed thrusting in the Alpine foreland of northern Italy and transpressional and dextral strike-slip deformation in NW Slovenia (Fig. 1). This region is characterised by moderate rates of seismicity (Poljak et al., 2000; Bressan et al., 2007) with three significant earthquakes recorded in the last 30 years: the 1976 Friuli $M_{w}=6.4$ event across the Italian border (e.g. Perniola et al., 2004), the $1998 M_{w}=5.6 \mathrm{Krn}$ mountains earthquake (Gosar et al., 2001; Bajc et al., 2001) and the 2004 Krn mountains $M_{w}=5.2$ event (Cecić et al., 2005; Aoudia et al., 2005). On 12 April 1998, Easter day, a moderate size earthquake $\left(M_{w}=5.6\right)$, occurred at the junction between the Alps and the Dinarides mountain chain (NW Slovenia). The main shock, a $12 \mathrm{~km}$ right lateral strike-slip event on the Ravne fault zone, occurred on a sub-vertical fault plane. The rupture, confined between 3 and $9 \mathrm{~km}$ depth, with no evidence of surface faulting, propagated bilaterally within two structural barriers (Bajc et al., 2001). The maximum intensity of this earthquake was VII-VIII EMS-98 (Zupančič et al., 2001).

On 12 July 2004 at 13:04 UTC a moderate $\left(M_{w}=5.2\right)$ earthquake shook Slovenia and surrounding countries. The epicentre of the event was in NW Slovenia, in Soča valley,

Published by Copernicus Publications on behalf of the European Geosciences Union. 


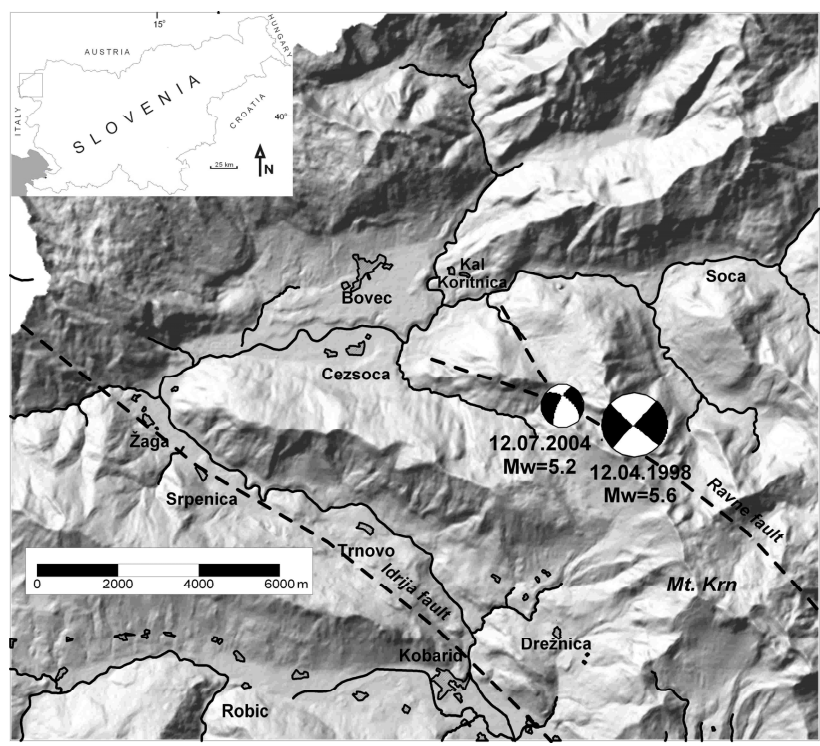

Fig. 1. Study area in Western Slovenia. The area topography is shown as a shaded relief image (artificial illumination from the northwest). Dashed lines indicate traces of active faults oriented NW-SE. Beach balls indicate focal mechanisms of the strong earthquake of 12 April $1998\left(M_{w}=5.6\right)$ and 12 July $2004\left(M_{w}=5.2\right)$. Both mechanisms show strike-slip kinematics.

close to the epicentre of the $1998\left(M_{w}=5.6\right)$ earthquake. According to the field surveys (Cecić et al., 2005), the localities with the most damage are small town Bovec and village Cezsoca, both in the valley of the river Soča. The maximum intensity was VI-VII EMS-98. No collapses or partial collapses of walls and houses were reported. However, more than 1100 houses were damaged, 175 of them are considered to be temporarily unsafe for the inhabitants. One person was killed in the rockslide triggered by the earthquake, and several were injured. Strong site effects caused by very heterogeneous glacio-fluvial sediments were characteristic for both earthquakes (Gosar et al., 2001; Gosar, 2007).

The geology of the Italy-Slovenia border area comprises a thick Mesozoic carbonate thrust stack that was overthrusted towards the SSW during the middle Tertiary. Parallel NWstriking Dinaric dextral strike-slip faults such as the Ravne and Idrija faults (Fig. 1; Kastelic and Cunningham, 2006) cut through the mountains at high angle with no apparent connection to pre-existing topography and older structures formed during Alpine nappe stacking. The Ravne fault which was responsible for both strong earthquakes is interpreted as an actively propagating NW-SE trending dextral strike-slip fault which is segmented. The growing fault reactivates older NW-SE striking planes formed during thrusting (Kastelic et al., 2006).

The largest earthquake ever recorded in the AlpsDinarides junction was the 1511 western Slovenia earthquake $\left(M_{w}=6.8\right)$ which was responsible for at least 12000 deaths. The exact location and mechanism of the 1511 event are debated and no surface ruptures associated with the event have yet been documented (Fitzko et al., 2005). It is possible that the 1511 event ruptured a segment of the Idrija fault further to the southeast of our study area thus leaving behind it a seismic "gap". Using stress transfer calculations it is possible to evaluate the exposure of this seismic gap to the 1998 and 2004 earthquakes.

\section{Method}

Large earthquakes on fault planes can trigger subsequent earthquakes at short distances from the epicentre by transferring static or dynamic stresses (e.g. Harris et al., 1995; Stein et al., 1997; Gomberg et al., 2001; Parsons et al., 2006). We computed static stress changes due to simple, planar slip along the source faults using the DLC set of computer codes by R. Simpson (USGS). We compute the Coulomb stress change in an elastic half-space (Okada, 1992) by assuming a shear modulus of $3.0 \times 10^{10} \mathrm{~Pa}$, Poisson's ratio 0.25 and effective coefficient of friction $\mu /=0.4$. Value 0.4 was adopted as is closer to friction values for major faults (Harris and Simpson, 1998).

The fault slip models are based on the seismological data by Bajc et al. (2001), Aoudia et al. (2005), Živčić et al. (2006) and Kastelic et al. (2006). All source faults are strike- slip planes and their slip models are given in Table 1. Modeling parameters are summarized in Table 2. The 124-1998 rupture plane has almost double length $(12 \mathrm{~km})$ than the 12-7-2004 $(5 \mathrm{~km})$. The length of the latter was chosen as a compromise between the maximum rupture suggested by the empirical relationships of Wells and Coppersmith (1994) for a $M_{w}=5.2$ event $(L=4.3 \mathrm{~km})$ and by the data of Živčić et al. (2006). Both sources were modeled as inclined, rectangular dislocations ignoring local fault complexities. We also used uniform slip models as there are no published slip distribution data for those events. We calculated the change in the Coulomb Failure Function (CFF; or Coulomb stress) on target failure planes (e.g. Reasenberg and Simpson, 1992),

$\Delta \mathrm{CFF}=\Delta \tau+\mu^{\prime} \Delta \sigma_{n}$

where $\Delta \tau$ is the co-seismic change in shear stress on the receiver fault and in the direction of fault slip, $\Delta \sigma_{n}$ is the change in normal stress (with tension positive), and $\mu^{\prime}$ is the effective coefficient of friction,

$\mu^{\prime}=\mu\left(1-\Delta P / \Delta \sigma_{n}\right)$

where $\mu$ is the static coefficient of friction and $\Delta P$ is the pore pressure change within the fault. $\triangle \mathrm{CFF}$ is the Coulomb stress change between the initial, Coulomb stress and the final stress. $\triangle \mathrm{CFF}$ was sampled on a horizontal section at $7 \mathrm{~km}$ depth (hypocentre depth of both mainshocks) on a $100 \times 100 \mathrm{~km}$ grid surrounding the source event epicentre, 
Table 1. The slip models of source faults shown in Figs. 2 and 3. Features include: Source event epicentre coordinates (latitude-longitude), Fault length, strike (clockwise from North), dip, rake, average dip slip per event, average strike slip per event, Earthquake Magnitude, Fault width is $6 \mathrm{~km}$ in 1998 and $5 \mathrm{~km}$ in 2004. RL and LL indicate right-lateral and left-lateral slip model, respectively.

\begin{tabular}{lccccccccc}
\hline Name & Epicentre & Depth $(\mathrm{km})$ & Length $(\mathrm{km})$ & Strike & Dip $\left(^{\circ}\right)$ & Rake & $U_{d}(\mathrm{~m})$ & $U_{s}(\mathrm{~m})$ & $M_{w}$ \\
\hline 1998 fault & $46.303-13.628$ & 7.6 & 12 & 132 & 86 & 178 & -0.004 & -0.116 & 5.6 \\
2004 fault (RL) & $46.308-13.616$ & 7.0 & 5 & 307 & 56 & -156 & -0.03 & -0.07 & 5.2 \\
2004 fault (LL) & $46.308-13.616$ & 7.0 & 5 & 204 & 71 & -36 & -0.03 & -0.07 & 5.2 \\
\hline
\end{tabular}

with $1 \mathrm{~km}$ grid spacing. First, we used the program ELFGRID to calculate a stress tensor grid at $7 \mathrm{~km}$ depth due to coseismic dislocations. Then we applied the program STROP which uses that tensor to calculate the tractions at that depth on planes of specified orientation and rake of the slip vector such as those matching the either the 2004 slip model (Fig. 2) or the 1998 slip model (Fig. 3). STROP outputs a $\triangle$ CFF file that does the calculation in Eq. (1) above on the planes of interest for the friction value specified (see results in Figs. 2 and 3). We also calculated stress changes on optimal planes to regional compression (Fig. 4). The spatial distribution of the Coulomb stress has a lobate pattern which is often approximately symmetric with respect to fault rupture. We interpret a positive value of $\triangle \mathrm{CFF}$ to mean that a fault plane occurring within this lobe has been brought closer to failure; when $\triangle \mathrm{CFF}$ is negative, the fault is brought further from failure (i.e. relaxed).

\section{Stress changes on the active faults}

First, we compute stress changes along right-lateral, target strike-slip faults due to the 1998 earthquake (Fig. 2) using the parameters listed in Table 1. We estimated a strike-slip displacement of $11.6 \mathrm{~cm}$ and a dip-slip displacement of $0.4 \mathrm{~cm}$ for a magnitude $M_{w}=5.6$ using the Hanks and Kanamori formula [1979; $M_{w}=(2 / 3) \times\left(\log M_{o}-16.05\right)$; where $M_{o}$ is the scalar moment of the best double couple in dyne-cm]. Our calculations were done at $7 \mathrm{~km}$ depth that is the hypocentral location of the 2004 earthquake. We calculated Coulomb stress for 2004-type target faults (Fig. 2a) for 1998-type target faults (Fig. 3) and for left-lateral target slip planes (Fig. 2b). We also plot the relocated epicentres of the 1998 sequence by Bajc et al., (2001; 129 events above $M l=1.6$; Figs. 2, 3a and 4) and the 2004 aftershocks (111 events above $M l=1.6$; Figs. 2, 3 and 4; Živčić, 2005 ${ }^{1}$ ), respectively. In Fig. 2, we suggest that the crustal volume adjacent to the 1998 rupture is relaxed (blue and dark colour), however, a) almost all the 1998 aftershock sequence occurred within

\footnotetext{
${ }^{1}$ Živčić, M.: Catalogue of instrumentally located earthquakes in Slovenia 1981-2005, Environmental Agency of the Republic of Slovenia, Seismology and Geology Office, unpublished material, 2005.
}

Table 2. Input parameters used for stress transfer modeling.

\begin{tabular}{ll}
\hline Poisson ratio & 0.25 \\
Shear modulus & $\mu=300.000 \mathrm{bar}$ \\
Map Projection & UTM zone 33 \\
Depth of $\Delta$ CFF calculation & $7 \mathrm{~km}$ \\
Grid Size & $1 \mathrm{~km}$ \\
Friction Coefficient $\left(\mu^{\prime}\right)$ & 0.4 \\
Target Planes (dextral) & $307 / 56 \mathrm{NE} /-156$ \\
Target Planes (sinistral) & $204 / 71 \mathrm{NW} /-36$ \\
\hline
\end{tabular}

$4 \mathrm{~km}$ away from the Ravne fault plane and inside the unloaded area where Coulomb stress is less than -2 bar and b) the 2004 epicentre is also located a bit further northwest of the 1998 epicentre and inside the black (relaxed) area. Then we computed stress changes along left-lateral target faults using the nodal plane parameters determined for the 2004 earthquake (Fig. 2b). Left-lateral faulting exists in western Slovenia although less pronounced than the right-lateral planes (Buser, 1986). A similar stress pattern emerged with minor differences at stress levels towards both ends of the Ravne-Krn mountain fault. Furthermore, Fig. 3 shows Coulomb stress changes for 1998-type dextral active faults after combining both earthquakes. The difference with Fig. 2a is a larger loading effect along strike which exceeds the level of +2 bar (white lobes at both ends of rupture) and an almost negligible loading effect $(<0.1$ bar) orthogonally at both ends of the 1998 rupture. The triggering threshold (0.1 bar; Harris and Simpson, 1998) is reached at about $8 \mathrm{~km}$ on either side of the combined rupture plane (Fig. 3).

\section{Stress changes on optimally oriented faults to the re- gional stress field}

Then, we computed Coulomb stress change on optimally oriented fault planes at $7 \mathrm{~km}$ depth from the $1998 M_{w}=5.6$ earthquake (Fig. 4a). Optimal orientations were calculated using principal strain vectors from Grenerczy et al. (2000; $\mathrm{N} 195^{\circ} \mathrm{E}$ ) that were confirmed by Serpelloni et al. (2006). We used a friction coefficient of 0.4 and a remote stress 

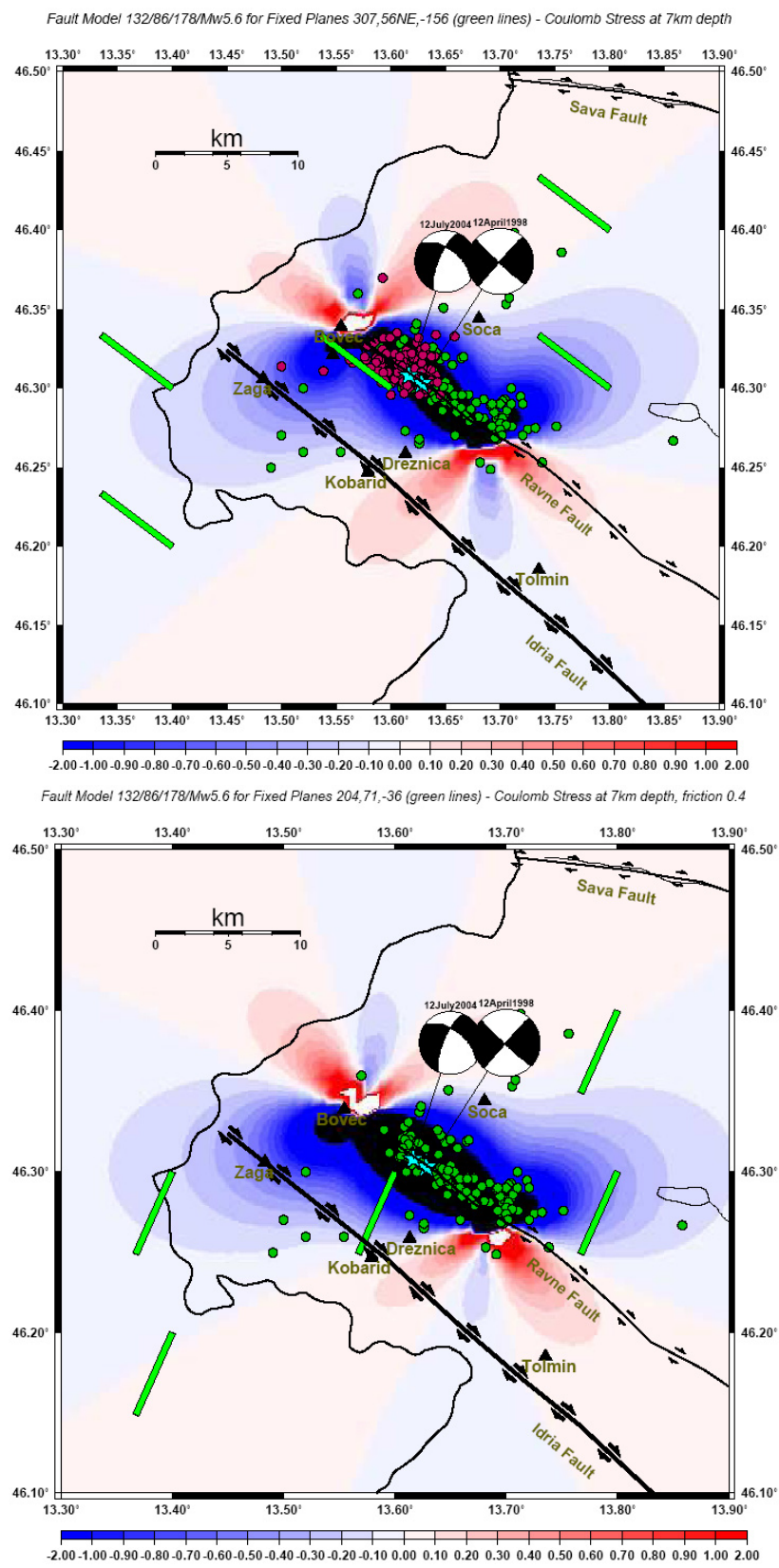

Fig. 2. (a) Static stress change after the 1998 main shock for rightlateral target faults with kinematics identical to the 2004 rupture. Blue areas indicate unloading, red areas indicate loading, respectively. Slip models are shown in Table 1. (b) Static stress change after the 1998 main shock for left-lateral target faults (with kinematics identical to the 2004 nodal rupture plane). Beachballs represent low hemisphere, equal area projections of fault plane solutions. Green dots are locations of 1998 event aftershocks (Bajc et al., 2001) and red dots locations of 2004 event aftershocks (Kastelic et al., 2006). Colour scale in bar ( 1 bar=100 KPa). Scale saturates at +2 bar (white) or -2 bar (black).

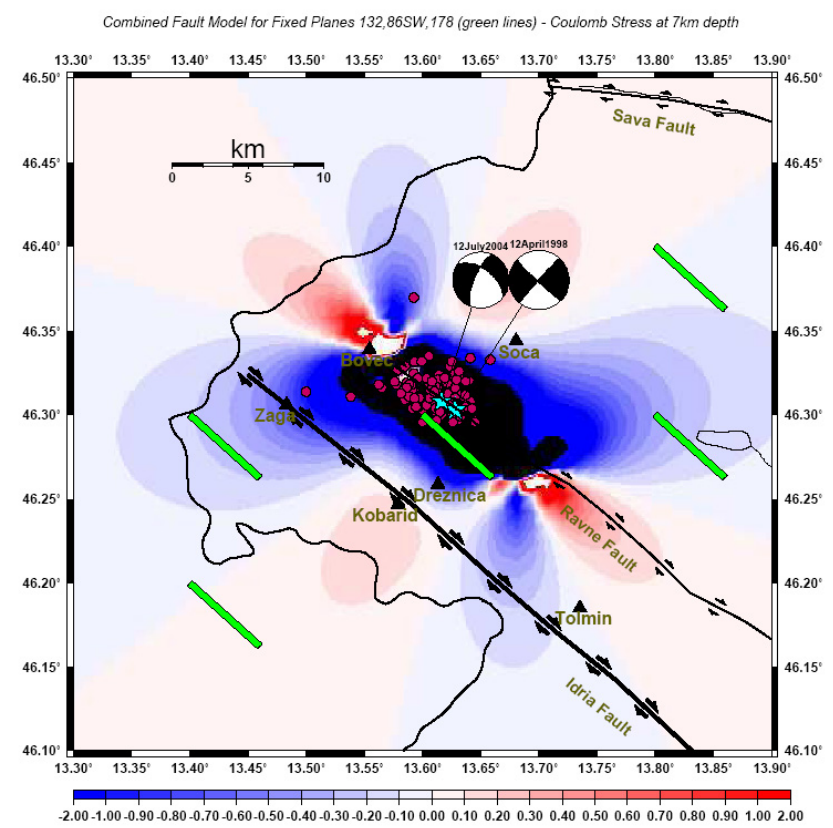

Fig. 3. Static stress change after the 1998 and 2004 main shocks for right-lateral target faults with kinematics identical to the 1998 rupture. Blue areas indicate unloading, red areas indicate loading, respectively. Red dots indicate locations of 2004 event aftershocks (Kastelic et al., 2006). Colour scale in bar (1 bar=100 KPa). Scale saturates at +2 bar (white) or -2 bar (black).

loading of $200 \mathrm{bar}(20 \mathrm{MPa})$ to secure that regional stress is larger than co-seismic stress drop. Figure 4 shows that the region containing the greatest strain (stress) direction is relaxed (blue colour). Sensitivity analysis in other compressional environments (e.g., Pakistan; Parsons et al., 2006) shows that the relaxed Coulomb stress lobe rotates as the greatest regional stress rotates. So we assume that a 10-degree uncertainty in the direction of the principal stress would not alter much the stress pattern in Fig. 4. This assumption seems reasonable as Serpelloni et al. (2006), calculated 1- $\sigma$ uncertainty of $7^{\circ}$ for this area and Bressan et al. (1998) calculated a $\mathrm{N} 185^{\circ} \mathrm{E}$ direction of maximum horizontal stress.

We suggest that the Coulomb stress pattern explains the occurrence of many off-fault aftershocks located at the southeastern end of the 1998 rupture. We investigate this further by projecting the 1998 aftershocks on a vertical section of Coulomb stress including events located on either side of the SE termination of the rupture $\left(13.7^{\circ} \mathrm{E}, 46.27^{\circ} \mathrm{N}\right.$; marked by cyan square in Fig. 4). The cross-section (Fig. 5) is oriented $\mathrm{N} 42^{\circ} \mathrm{E}$ (normal to Ravne fault) and extends $6 \mathrm{~km}$ along the NW-SE direction (along strike) and $20 \mathrm{~km}$ along the NE-SW direction (across strike). The modeling clearly demonstrates that 38 out of 42 selected aftershocks plot in loaded (red) areas. The relaxed area at the centre of the section and at depths between 5 and $10 \mathrm{~km}$ represents the termination of the 1998 rupture. We observe that the majority of those events 

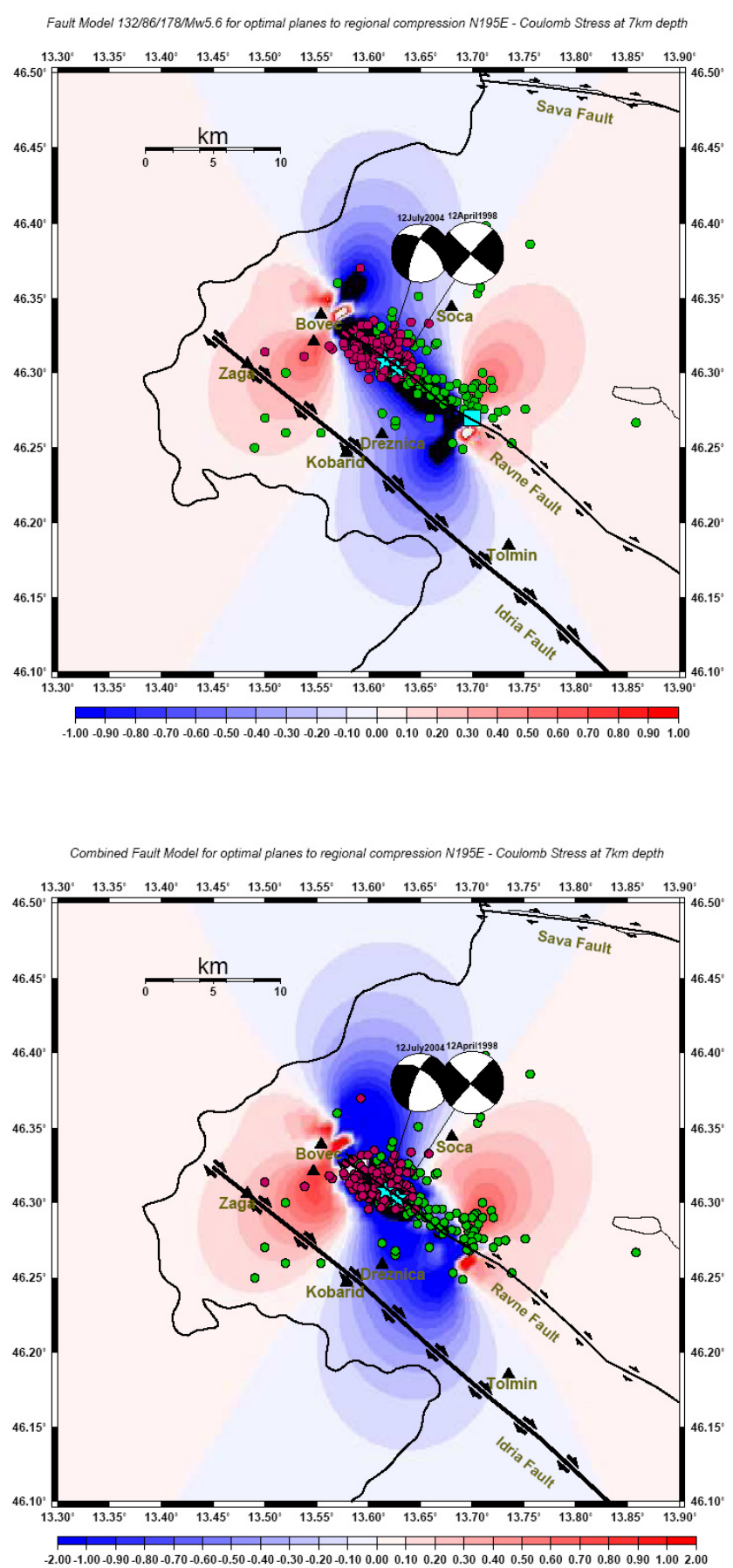

Fig. 4. (top). Static stress change after the 1998 main shock for fault planes optimally oriented to regional compression $\left(\mathrm{N} 195^{\circ} \mathrm{E}\right.$; Grenerczy et al., 2000; Serpelloni et al., 2006). (bottom) combined $(1998+2004)$ stress change for optimally-oriented planes. Blue areas indicate unloading, red areas indicate loading, respectively. Effective coefficient of friction is 0.4 in all cases. Slip models are shown in Table 1. Beachballs represent low hemisphere, equal area projections of fault plane solutions. Colour scale in bar $(1 \mathrm{bar}=100 \mathrm{KPa})$.

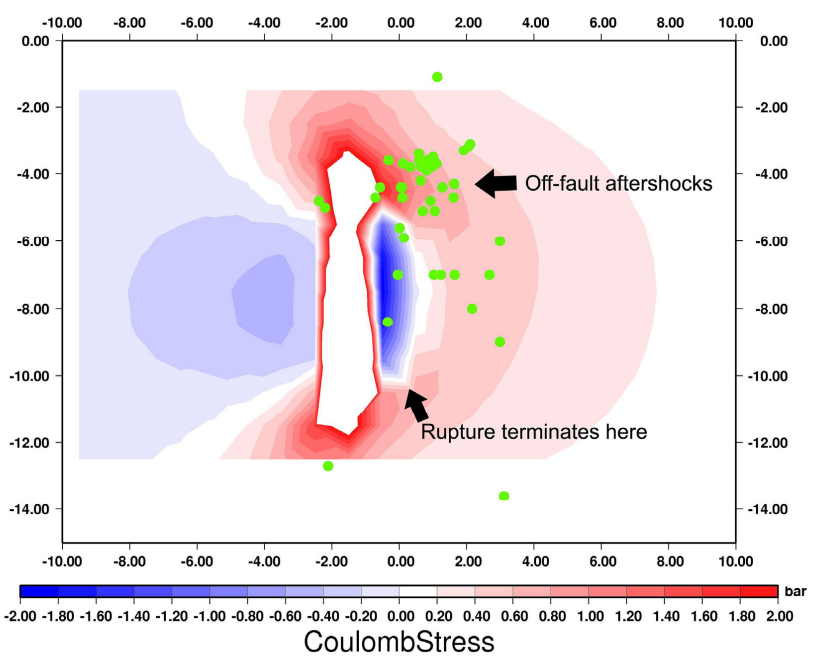

Fig. 5. Cross-section oriented $\mathrm{N} 42^{\circ} \mathrm{E}$ showing static Coulomb changes on optimal planes following the 1998 earthquake in NW Slovenia. Positive (reddish) levels promote failure; negative (bluish) levels promote relaxation, respectively. The centre of the section is located about $6.5 \mathrm{~km}$ to the SE of the 1998 epicentre and it is indicated by a cyan square in Fig. 4a. Numbers on ticks denote kilometres.

occurred above the rupture at depths $3-5 \mathrm{~km}$ and to the northeast; therefore we interpret those as "off-fault aftershocks".

Adding the stress change due to $2004 M_{w}=5.2$ earthquake (Fig. 4b) we note that all off-fault aftershocks on the northwest end of the rupture are inside the positive (loaded) stress lobe, as well. The Coulomb stress change due to the 2004 mainshock does not have an effect on the geometry of the stress lobes but on the level of combined stress change (Fig. 4b). This is not surprising given the similarity in the focal plane solutions. We also note that the region near the town of Bovec has received a total Coulomb stress of 2 bar following the 2004 event so this loading indicates to us an increase in the seismic hazard under a renewal model of earthquake recurrence (e.g. Parsons et al., 2000).

\section{Discussion - conclusions}

a. Locations of the 1998 and 2004 events and triggered seismicity. It can be easily seen that the epicentres of both events are very close in space (Fig. 1). In fact, their epicentral distance is only $1.1 \mathrm{~km}$ while the 2004 epicentre is located to the northwest of the 1998 event, i.e. along strike of the Ravne fault. Our Coulomb stress calculations fail to explain the location of the 2004 event as its epicentre falls inside the relaxed area of the 1998 earthquake. One possible explanation for this apparent discrepancy is that we used a uniform slip model while the 2004 event may have ruptured a locked patch of the Ravne fault, which remained outside the 1998 slip zone. 
Indeed, the map of slip distribution of Bajc et al. (2001; their Fig. 4) shows a slip-free patch about $3 \mathrm{~km}$ to the northwest of the 1998 epicentre. This area may have been loaded by the 1998 mainshock.

We also note that the epicentres of aftershocks are also clustered within stress shadows (Figs. 2 and 3), for Coulomb stresses resolved along target faults bearing 1998 and 2004-type kinematics. However, considering failure along optimally oriented planes over $2 / 3$ of the aftershocks located at both ends of the rupture falls within the loaded area (see distribution in Figure 4 and cross-section in Fig. 5). This percentage may be further increased if the regional compression direction is rotated a few degrees clockwise (as it may be possible according to Serpelloni et al., 2006) because the Coulomb stress lobes also rotate (Parsons et al., 2006). The positive correlation between aftershocks and positive stress lobes was also noted by Toda et al, (1998) who studied stress change patterns following the Kobe, $M_{w}=6.9$ earthquake and by Steacy et al. (2005) who studied four, recent earthquake sequences in Southern California (Landers, Loma Prieta, Hector Mine and Northridge; all events with $\left.M_{w}>6.5\right)$. Furthermore, a similar distribution was observed during the 2005 eastern-Aegean sequence (Benetatos et al., 2006; three events with $\left.M_{w}<6.0\right)$ and by Karakostas et al. (2003) and Ganas et al. (2005) during the 2001 Skyros earthquake sequence $\left(M_{w}=6.4\right)$ where Coulomb stress resolved along optimal planes could explain the majority of the off-fault aftershocks. Recently, Chi and Hauksson (2006) showed that static stress increase due to a $M_{w}=5.0$ earthquake could explain triggered perpendicular seismicity at both ends of a strike-slip rupture. Our interpretation of these results is that elastic stress transfer can explain most of the spatial distribution of "offfault aftershocks" when the regional stress field is considered. On the other hand, Coulomb stress calculations along specified (target) planes are more useful towards re-evaluating seismic hazard from well-studied structures (i.e. with well-understood seismic history) which are capable to produce new, strong earthquakes (mainshocks).

b. Future seismicity implications of the Krn mountain earthquakes. In this paper we discuss the implications for future seismicity patterns in NW Slovenia but we make no attempt to calculate revised magnitudes of expected events, forecast earthquakes or compute expected ground motions. Rather, we make use of empirical evidence that stress transfer may bring closer to failure or delay another large earthquake (Harris and Simpson, 1998; Toda et al., 1998; Parsons et al., 2000) so it may be used to modify earthquake probability estimates. In this sense, our results suggest that seismic hazard is increased along strike the Ravne fault to the southeast (Figs. 2a, 3; Cunnigham et al., 2006). A similar effect occurs near the town of Bovec at the NW end of the ruptures. The post-2004 stress load along the Ravne fault zone decays beyond the 0.1 bar at distances about $8 \mathrm{~km}$ from the ends of the rupture. This short distance is due to the moderate magnitudes of both earthquakes and the relatively low angle of effective friction coefficient. Higher values of the coefficient of friction are expected to raise the stress levels marginally along strike (e.g. Parsons et al., 2006) but the lobe geometry is unaffected. So it depends on the state of the seismic cycle of the neighbouring faults to estimate the effect of the extra load as the effect would be bigger along faults that are late on their cycle. This should be further investigated by other methods including space geodesy to estimate slip rates and paleo-seismology to obtain recurrence intervals.

Bajc et al. (2001) suggest that the northwestern barrier of the 1998 rupture is at the Bovec basin, located in the transition zone between Dinaric and Alpine structures where there is a sharp change in the geometry of faulting. Our calculations show that this area has undergone an increase in stress levels because of static stress transfer. This increase is greater than 2 bar near the town of Bovec. Bajc et al. (2001) also suggest that the southeastern barrier of the 1998 event is within the Dinaric system of right-lateral strike-slip faults and its surface expression corresponds to the Tolminka-spring perched basin, a $1 \mathrm{~km}$ restraining stepover structure (Kastelic et al., 2006). At this site, the Ravne fault overlaps with a $30 \mathrm{~km}$ strike-slip fault segment of the Idrija fault zone that is free of aftershocks. Our calculations (Fig. 3) show that a significant portion of the Idrija fault is inside the stress shadow of the 1998-2004 earthquakes so the seismic hazard from this fault is reduced.

Moreover, we observe that the region to the east of the town of Zaga comprises a loaded area (in Fig. 4b; 0.20.4 bar; at $7 \mathrm{~km}$ depth). This does not imply that the Idrija fault has itself been loaded by that amount (see Fig. 3 for the relevant stress change map), but optimally oriented faults to regional compression in this area have been loaded. We also note that this area is located 30 $\mathrm{km}$ to the east of the 1976 Friuli events where positive Coulomb stresses of the order of $0.1-0.2$ bar have been estimated by Perniola et al. (2004). Therefore, the combined, post-2004 load in this area may reach 0.6 bar. We conclude that the area between the towns of Bovec and Zaga should be further investigated for active structures so that the seismic hazard is better evaluated. In case those structures exist and are optimally oriented to the regional compression then a worst-case scenario would be that an earthquake is triggered along one optimal fault plane which in turn could load the neighbouring Idrija fault. 
Acknowledgements. Funding was provided by the General Secretariat for Research and Technology of Greece (GSRT) and the Ministry for Science and Higher Education of Slovenia. We thank two anonymous reviewers for comments and the Associate Editor for his assistance. We also thank D. Cunningham, M. Poljak, R. Harris and T. Parsons for discussions and B. Simpson for making his stress transfer code available. The authors are indebted to M. Zivcic and J. Bajc for relocated earthquake data. All illustrations were prepared using the GMT software.

Edited by: M. Contadakis

Reviewed by: two anonymous referees

\section{References}

Aoudia, A., Zille, A., Borghi, A., Riva, R., Barzaghi, R., Živčić, M., and Panza, G.: The July 2004 Western Slovenia earthquake: From localised fault-scale complexities to distributed deformation at the junction between the south-eastern Alps and External Dinarides, Geophys. Res. Abstr., 7, 09258, 2005.

Bajc, J., Aoudia, A., Sarao, A., and Suhadolc, P.: The 1998 BovecKrn mountain (Slovenia) earthquake sequence, Geophys. Res. Lett., 28, 1839-1842, 2001.

Battaglia, M., Murray, M. H., Serpelloni, E., and Bürgmann, R.: The Adriatic region: An independent microplate within the Africa-Eurasia collision zone, Geophys. Res. Lett., 31, L09605, doi:10.1029/2004GL019723, 2004.

Benetatos, C., Kiratzi, A., Ganas, A., Ziazia, M., Plessa, A., and Drakatos, G.: Strike-slip motions in the Gulf of Sigacik (western Turkey): Properties of the 17 October 2005 earthquake seismic sequence, Tectonophysics, 426(3-4), 263-279, 2006.

Bressan, G., Snidarcig, A., and Venturini, C.: Present state of tectonic stress of the Friuli area (eastern Southern Alps), Tectonophysics, 292(3-4), 211-227, 1998.

Bressan, G., Kravanja, S., and Franceschina, G.: Source parameters and stress release of seismic sequences occurred in the FriuliVenezia Giulia region (Northeastern Italy) and in Western Slovenia, Physics of the Earth and Planetary Interiors, 160(3-4), 192214, 2007.

Buser, S.: Basic geological map of Yugoslavia 1:100000 - sheet Tolmin and Videm, Geological Survey of Slovenia, 1986.

Cecić, I., Kobal, M., Kolar, J., Pahor, J., Vidrih, R., Živčić, M., Carman, M., and Jesenko, T.: The 12 July 2004 MLV = 4.9 Upper Soca valley (SW Slovenia) Earthquake, Geophys. Res. Abstr., 7, 07942, 2005.

Chi, W.-C. and Hauksson, E.: Fault-perpendicular aftershock clusters following the $2003 M_{w}=5.0$ Big Bear, California, earthquake, Geophys. Res. Lett., 33, L07301, doi:10.1029/2005GL025033, 2006.

Cunningham, D., Grebby, S., Tansey, K., Gosar, A., and Kastelic, V.: Application of airborne LiDAR to mapping seismogenic faults in forested mountainous terrain, southeastern Alps, Slovenia, Geophys. Res. Lett., 33(20), L20308, doi:10.1029/2006GL027014, 2006.

D’Agostino, N., Cheloni, D., Mantenuto, S., Selvaggi, G., Michelini, A., and Zuliani, D.: Strain accumulation in the southern Alps (NE Italy) and deformation at the northeastern boundary of Adria observed by CGPS measurements, Geophys. Res. Lett., 32(19), L19306, doi:10.1029/2005GL024266, 2005.
Fitzko, F., Suhadolc, P., Aoudia, A., and Panza, G. F.: Constraints on the location and mechanism of the 1511 Western Slovenia earthquake from active tectonics and modeling of macroseismic data, Tectonophysics, 404, 77-90, 2005.

Ganas, A., Drakatos, G., Pavlides, S. B., Stavrakakis, G. N., Ziazia, M., Sokos, E., and Karastathis, V. K.: The $2001 M_{w}=6.4$ Skyros earthquake, conjugate strike-slip faulting and spatial variation in stress within the central Aegean Sea, J. Geodynamics, 39(1), 6177, 2005 .

Gomberg, J., Reasenberg, P. A., Bodin, P., and Harris, R. A.: Earthquake triggering by seismic waves following the Landers and Hector mine earthquakes, Nature, 411, 462-466, 2001.

Gosar, A., Stopar, R., Car, M., et al.: The earthquake on 12 April 1998 in the Krn Mountains (Slovenia): ground-motion amplification study using microtremors and modeling based on geophysical data, J. Appl. Geophys., 47(2), 153-167, 2001.

Gosar, A.: Microtremor HVSR study for assessing site effects in the Bovec basin (NW Slovenia) related to $1998 M_{w} 5.6$ and 2004 $M_{w} 5.2$ earthquakes, Eng. Geol., 91, 178-193, 2007.

Grenerczy, G., Kenyeres, A., and Fejes, I.: Present crustal movement and strain distribution in Central Europe inferred from GPS measurements, J. Geophysical Res., 105(B9), 21 835-21 846, doi:10.1029/2000JB900127, 2000.

Hanks, T. C. and Kanamori, H.: A moment magnitude scale, J. Geophys. Res., 84, 2348-2350, 1979.

Harris, R. A., Simpson, R. W., and Reasenberg, P. A.: Influence of static stress changes on earthquake locations in southern California, Nature, 375, 221-224, 1995.

Harris, R. A. and Simpson, R. W.: Suppression of large earthquakes by stress shadows: A comparison of Coulomb and rate-and-state failure, J. Geophys. Res., 103, 24 439-24 451, 1998.

Karakostas, V. G., Papadimitriou, E. E., Karakaisis, G. F., Papazachos, C. B., Scordilis, E. M., Vargemezis, G., and Aidona, E.: The 2001 Skyros, Northern Aegean, Greece, earthquake sequence: off - fault aftershocks, tectonic implications, and seismicity triggering, Geophys. Res. Lett., 30(1), 1012, doi:10.1029/2002GL015814, 2003.

Kastelic, V. and Cunningham, D.: Multi-disciplinary investigation of active strike-slip fault propagation in the Julian Alps: The Ravne Fault, NW Slovenia, Geophys. Res. Abstr., 8, 05018, 2006.

Kastelic, V., Živčić, M., Pahor, J., and Gosar, A.: Seismotectonic characteristics of the 2004 earthquake in Krn mountains, Potresi v letu 2004, 78-87, 2006 (in Slovenian, with English summary).

Nostro, C., Chiaraluce, L., Cocco, M., Baumont, D., and Scotti, O.: Coulomb stress changes caused by repeated normal faulting earthquakes during the 1997 Umbria-Marche (central Italy) seismic sequence, J. Geophys. Res., 110, B05S20, doi:10.1029/2004JB003386, 2005.

Okada, Y.: Internal deformation due to shear and tensile faults in a half-space, Bulletin of Seismological Society of America, 82, 1018-1040, 1992.

Parsons, T., Toda, S., Stein, R. S., Barka, A., and Dieterich, J. H.: Heightened odds of large earthquakes near Istanbul: An interaction-based probability calculation, Science, 288, 661-665, 2000.

Parsons, T.: Significance of stress transfer in time-dependent earthquake probability calculations, J. Geophys. Res., 110(B5), B05S02, doi:10.1029/2004JB003190, 2005. 
Parsons, T., Yeats, R. S., Yagi, Y., and Hussain, A.: Static stress change from the 8 October, $2005 \mathrm{M}=7.6$ Kashmir earthquake, Geophys. Res. Lett., 33(6), L06304, doi:10.1029/2005GL025429, 2006.

Perniola, B., Bressan, G., and Pondrelli, S.: Changes in failure stress and stress transfer during the 1976-77 Friuli earthquake sequence, Geophys. J. Int., 156(2), 297-306, doi:10.1111/j.1365246X.2003.02146.x, 2004.

Poljak, M., Živčić, M., and Zupančič, P.: The seismotectonic characteristics of Slovenia, Pure Appl. Geophys., 157, 27-55, 2000.

Reasenberg, P. A. and Simpson, R. W.: Response of regional seismicity to the static stress change produced by the Loma Prieta earthquake, Science, 255, 1687-1690, 1992.

Serpelloni, E., Anzidei, M., Baldi, P., Casula, G., and Galvani, A.: GPS measurement of active strains across the Apennines, Annals of Geophysics, 49(1), 319-329, 2006.

Steacy, S., Nalbant, S. S., McCloskey, J., Nostro, C., Scotti, O., and Baumont, D.: Onto what planes should Coulomb stress perturbations be resolved?, J. Geophys. Res., 110, B05S15, doi:10.1029/2004JB003356, 2005.
Stein, R. S., Barka, A. A., and Dieterich, J. H.: Progressive failure on the North Anatolian fault since 1939 by earthquake stress triggering, Geophys. J. Int., 128, 594-604, 1997.

Toda, S., Stein, R. S., Reasenberg, P. A., Dieterich, J. H., and Yoshida, A.: Stress transferred by the $1995 M_{w}=6.9$ Kobe, Japan, shock: effect on aftershocks and future earthquake probabilities, J. Geophys. Res., 103, 24 453-24 565, 1998.

Wells, D. L. and Coppersmith, K. J.: New empirical relationships among magnitude, rupture length, rupture width, rupture area, and surface displacement, Bulletin of the Seismological Society of America, 84, 974-1002, 1994.

Zupančič, P., Cecić, I., Gosar, A., Placer, L., Poljak, M., Živčić, M.: The earthquake of 12 April 1998 in the Krn Mountains (Upper Soča valley, Slovenia) and its seismotectonic characteristics, Geologija, 44, 169-192, 2001.

Živčić, M. and Krn-2004 team: The Krn mountains (Slovenia) $M_{w}$ 5.2 earthquake: data acquisition and preliminary results, Geophys. Res. Abstr., 8, 06439, 2006. 